\title{
PENGARUH JUS JAMBU BIJI (PSIDIUM GUAJAVA) TERHADAP KADAR HEMOGLOBIN PADA IBU HAMIL ANEMIA
}

\section{EFFECT OF GUAVA JUICE (PSIDIUM GUAJAVA) ON HEMOGLOBIN LEVELS IN PREGNANT ANEMIA}

\author{
Noviana Luthfi Jayanti ${ }^{*}$; Sunarto; Yuwono Setiadi
}

\begin{abstract}
Background : Iron deficiency anemia is a national health problem that many pregnant women experience. Based on data from Riskesdas Results of 2013, the prevalence of anemia in pregnant women is $37.1 \%$. The rate of anemia in Central Java in 2015 reached 56.2\%. The government program to overcome the incidence of iron deficiency anemia in the form of giving of Fe tablet for 90 days with dose of $60 \mathrm{mg}$, beside Fe tablet also needed to support factor of iron absorption in hemoglobin synthesis process. Guava is a food ingredient that contains micronutrients needed in the synthesis of hemoglobin such as iron and vitamin $C$.
\end{abstract}

Objective : To know the effect of red guava juice on hemoglobin level in pregnancy anemia.

Method : This research used pre-test post-test control group design. Samples each group as many as 11 people. Interventions performed on the treatment group giving of guava juice for 20 days in pregnant women who consumed Fe tablets, while the control group only consumed Fe tablets. The test used to know the effect of treatment on hemoglobin levels using anova repeated measure with $\alpha=0.05$.

Results : The mean increase after intervention in the treatment group was $1.1 \mathrm{~g} / \mathrm{dl}$ and in the control group 0.7 $\mathrm{g} / \mathrm{dl}$. Based on the results of the anova test, there is the influence of guava juice and Fe tablet consumption on the insignificant hemoglobin level (0.439) after controlled by the intake of energy, protein, iron and vitamin $C$.

Conclusion : Guava juice for 20 days can increase hemoglobin level by $1.1 \mathrm{~g} / \mathrm{dl}$ although not statistically significant.

Keywords : guava juice, hemoglobin level, pregnancy anemia

\section{ABSTRAK}

Latar Belakang : Anemia defisiensi zat besi merupakan masalah kesehatan nasional yang banyak dialami ibu hamil. Berdasarkan data Hasil Riskesdas tahun 2013, prevalensi anemia pada bumil sebesar 37,1\%. Angka kejadian anemia di Jawa Tengah pada tahun 2015 mencapai 56,2\%. Program pemerintah dalam menanggulangi kejadian anemia defisiensi zat besi berupa pemberian tablet Fe selama 90 hari dengan dosis $60 \mathrm{mg}$, selain tablet Fe diperlukan juga faktor pendukung penyerapan zat besi dalam proses sintesis hemoglobin. Jambu biji merupakan bahan makanan yang mengandung zat gizi mikro yang diperlukan dalam sintesis hemoglobin seperti zat besi dan vitamin $\mathrm{C}$.

Tujuan : Untuk mengetahui pengaruh pemberian jus jambu biji merah terhadap kadar hemoglobin pada ibu hamil anemia.

Metode : Penelitian ini menggunakan rancangan pre-test pos-test control group design. Jumlah sampel masingmasing kelompok sebanyak 11 orang. Intervensi yang dilakukan pada kelompok treatment berupa pemberian jus jambu biji selama 20 hari pada ibu hamil yang mengkonsumsi tablet Fe, sedangkan kelompok kontrol hanya mengkonsumsi tablet Fe. Uji yang digunakan untuk mengetahui pengaruh treatment pada kadar hemoglobin menggunakan anova repeated measure dengan $\alpha=0,05$.

Hasil : Rerata peningkatan setelah intervensi pada kelompok treatment sebesar 1,1 gr/dl dan pada kelompok kontrol sebesar 0,7 gr/dl. Berdasarkan hasil uji anova terdapat pengaruh konsumsi jus jambu biji dan tablet Fe terhadap kadar hemoglobin yang tidak signifikan $(0,439)$ setelah dikontrol oleh asupan energi, protein, zat besi dan vitamin C.

Kesimpulan : Pemberian jus jambu biji selama 20 hari dapat meningkatkan kadar hemoglobin sebesar $1.1 \mathrm{gr} / \mathrm{dl}$ meskipun secara statistik tidak signifikan. 


\section{PENDAHULUAN}

Salah satu tujuan Sustainable Development Goals (SDGs) 2015 - 2030 yaitu mengurangi Angka Kematian Ibu (AKI). Target yang harus dicapai kurang dari 70 per 100.000 kelahiran hidup. ${ }^{1}$ Anemia gizi pada ibu hamil merupakan faktor pencetus penting dari kematian ibu melahirkan. Diperkirakan50\% ibu tidak mempunyai cadangan zat besi yang cukup selama kehamilannya, sehingga risiko defisiensi zat besi meningkat bersama dengan kehamilan ${ }^{2}$. Salah satu kebijakan program pemerintah yaitu menganjurkan agar ibu hamil mengkonsumsi tablet Fe selama 90 hari dengan dosis $60 \mathrm{mg}$, hal tersebut selaras dengan tujuan SDGs tahun 2015 - 2030 untuk mengurangi $\mathrm{AKI}^{3}$.

Berdasarkan data Hasil Riset Kesehatan Dasar (Riskesdas). ${ }^{4}$ Proporsi anemia pada ibu hamil (bumil) adalah sebesar 37,1 ibu hamil di Indonesia. Hasil studi pendahuluan yang dilakukan di Puskesmas Lerep menunjukkan data terakhir pada bulan Juli 2017, jumlah Ibu hamil anemia yang ada di wilayah kerja Puskesmas Lerep sebanyak 58 ibu hamil yang memiliki kadar $\mathrm{Hb}<11 \%$ yaitu $21,88 \%$ ibu dari jumlah ibu hamil ${ }^{5}$.

Anemia dalam kehamilan adalah kondisi ibu dengan kadar hemoglobin dibawah 11 gr\%. Menurut Departemen Kesehatan RI (2009) batas normal kadar hemoglobin untuk ibu hamil $\geq 11$ $\mathrm{g} / \mathrm{dl}^{6}$. Hemoglobin adalah protein berfigmen merah yang terdapat dalam sel darah merah yang berfungsi mengangkut oksigen dari paru-paru yang akan didistribusikan keseluruh tubuh ${ }^{7}$.

Pencegahan anemia defisiensi besi bisa dapat di lakukan dengan cara mengkonsumsi tablet tambah darah (Fe) dan dengan mengkonsumsi sumber bahan makanan yang menunjang penyerapan zat besi. Salah satunya yaitu sayur dan buah, karena sayur dan buah mengandung vitamin (C, A, B6, tiamin, niacin, E) dan mineral yang dapat mencegah anemia defisiensi besi.

Salah satu zat yang sangat membantu penyerapan zat besi adalah vitamin C (asam askorbat). Asam akan mereduksi ion feri menjadi fero dan menghambat terbentuknya kompleks Fe dengan makanan yang tidak larut ${ }^{8}$. Vitamin $\mathrm{C}$ dapat meningkatkan penyerapan besi non heme sebesar empat kali lipat dan dengan jumlah $200 \mathrm{mg}$ akan meningkatkan absorpsi besi sedikitnya $30 \%{ }^{9}$. Buah jambu biji mengandung asam askorbat 2 kali lipat dari jeruk yaitu sekitar 87 mg/100 gram jambu biji.

Tanaman jambu biji banyak ditemukan di wilayah pemukiman warga desa lerep, sehingga hal tersebut menjadi salah satu alasan pemilihan bahan menjadi produk untuk intervensi. Selain itu, kandungan zat gizi pada 100 gram buah jambu biji mengandung Energi 49 kal, Protein 0,9 gram, Lemak 0,3 gram, Karbohidrat 12,2 gram, Kalsium $14 \mathrm{mg}$, Fosfor $28 \mathrm{mg}$, Besi 1,1 mg, Vitamin A $25 \mathrm{SI}$, Vitamin B1 $0,05 \mathrm{mg}$ serat 5,6 gr dan Air 86 gram. Selain kandungan gizi, jambu biji juga mengandung zat fitokimia, salah satunya yaitu $\operatorname{tanin}^{10}$. Tanin dapat menghambat penyerapan zat besi di dalam tubuh, oleh karena itu pemilihan produk ini menggunakan jus jambu biji merah matang karena kandungan tanin yang didalam buah jambu biji matang lebih rendah dibandingkan dengan buah jambu biji yang tidak terlalu matang dan kandungan vitamin C jambu biji mencapai puncaknya menjelang matang.

Kebutuhan akan vitamin C seorang ibu hamil meningkat dari ibu yang tidak hamil, dimana seorang ibu hamil membutuhkan $85 \mathrm{mg}$ vitamin C per hari ${ }^{11}$. Sehingga untuk menunjang peningkatan kadar hemoglobin pada ibu hamil diperlukan bahan makanan yang mengandung zat besi dan vitamin $C$, bahan makanan tersebut dapat menjadi alternatif pendamping bagi ibu hamil untuk mengkonsumsi tablet Fe yang diberikan pemerintah ${ }^{12}$.

Berdasarkan data-data dan penjelasan yang telah dipaparkan diatas, anemia masih menjadi salah satu beban besar kesehatan dunia.Sehingga penulis merasa tertarik untuk meneliti tentang "Pengaruh Jus Jambu Biji terhadap Kadar Hemoglobin pada Ibu Hamil Anemia”.

\section{METODE}

Penelitian ini merupakan jenis penelitian eksperimental sungguhan (True Eksperimen Design) dengan Rancangan Penelitian yang digunakan dalam penelitian ini yaitu rancanganPre-Test PosTest Control Group Design. ,yang digunakan untuk mengetahui pengaruh konsumsi jus jambu biji terhadap kadar hemoglobin $(\mathrm{Hb})$ ibu hamil anemia, sebelum dan sesudah pemberian jus jambu biji.

Populasi dalam penelitian ini adalah jumlah seluruh Ibu Hamil anemia yang ada di wilayah kerja Puskesmas Lerep Kecamatan Ungaran Barat, Kabupaten Semarang yang berjumlah 44 orang pada bulan Februiari 2018.

Sampel penelitian ini adalah semua populasi dari sebagian ibu hamil anemia pada bulan Februari tahun 2018 di wilayah kerja Puskesmas Lerep Kecamatan Ungaran Barat, Kabupaten Semarang sesuai dengan perhitungan sampel dan kriteria inklusi , meliputi: Ibu hamil dengan kadar $\mathrm{Hb}$ < $11 \mathrm{gr} / \mathrm{dl}$, ibu hamil yang konsumsi tablet Fe, ibu hamil dengan LILA $\leq 23,5 \mathrm{~cm}$ ( Tidak KEK). Sedangkan kriteria eksklusi meliputi : Ibu hamil 
yang mengidap penyakit tertentu seperti preklamsia, jantung, kanker, HIV, Gestational Diabetes, TBC dan Ibu hamil yang melakukan pengobatan tertentu. Besar sampel dalam penelitian ini sebanyak 11 orang ibu hamil per kelompok, hasil tersebut didapat dengan menggunakan rumus Randomized Controlled Trial (Sample Size ).

Pengumpulan data dalam penelitian ini menggunakan data primer meliputi : Identitas sampel (dengan menggunakan formulir kuesioner identitas diri), Kadar $\mathrm{Hb}$ sebelum dan sesudah intervensi (menggunakan metode Auto analyzer yang dinyatakan dalam satuan $\mathrm{g} / \mathrm{dl}$ ) dan asupan makanan (menggunakan form recall $2 \times 24$ jam). Data kedua yaitu data sekunder meliputi gambaran umum lokasi penelitian yang meliputi data Ibu Hamil di wilayah kerja Puskesmas Lerep Kecamatan Ungaran Barat, Kabupaten Semarang.

Analisis data yang digunakan dalam penbelitian ini adalah Analisis Deskriptif dan Analisis Analitik. Analisis deskriptif bertujuan untuk mendiskripsikan karakteristik sampel dan karakteristik masing-masing variabel yang diteliti. Variabel yang berbentuk kategorik (Karakteristik responden meliputi usia, pekerjaan, pendidikan, usia kehamilan, asupan zat gizi). Variabel yang berbentuk numerik (kadar hemoglobin $\mathrm{Hb}$ pada kelompok kontrol dan perlakuan sebelum dan sesudah treatment) disajikan dalam bentuk mean, standar deviasi dan nilai minimum-maksimum dan Analisis Analitik untuk mengetahui pengaruh treatment pada kadar hemoglobin menggunakan ANOVA Repeated Measure dengan $\alpha=0,05$.

\section{HASIL}

Penelitian ini dilakukan diwilayah kerja Puskesmas Lerep, Kabupaten Semarang. Puskesmas Lerep merupakan puskesmas rawat inap yang terletak di Jalan Yudistira Raya KM 3, Lerep, Ungaran Barat, Semarang, Jawa Tengah, 50519. Puskesmas Lerep memeiliki wilayah kerja yang terdiri dari 6 desa, yaitu Branjang, Kalisidi, Lerep, Keji, Bandarjo dan Nyatnyono.

\section{Karakteristik Responden}

Penelitian ini dilakukan kepada ibu hamil anemia sebagai responden. Sebanyak 22 orang ibu hamil anemia yang memenuhi kriteria. Sampel penelitian dibagi menjadi dua kelompok yaitu kelompok perlakuan dan kelompok kontrol, masing-masing kelompok sebanyak 11 orang ibu hamil anemia.
Tabel 1. Distribusi Karakteristik Responden berdasarkan Umur lbu Hamil, Pendidikan Terakhir,Pekerjaan dan Usia Kehamilan pada bulan April 2018 di Wilayah Puskesmas Lerep

\begin{tabular}{|c|c|c|c|}
\hline $\begin{array}{l}\text { Karakteristik } \\
\text { Responden }\end{array}$ & $\begin{array}{c}\text { Kelompok } \\
\text { Perlakuan } \\
(\mathrm{n}=11)\end{array}$ & $\begin{array}{l}\text { Kelompok } \\
\text { Kontrol } \\
(n=11)\end{array}$ & $\begin{array}{c}\text { Total } \\
(n=22)\end{array}$ \\
\hline \multicolumn{4}{|l|}{ Umur Ibu } \\
\hline Normal & $9(81.8 \%)$ & $11(100 \%)$ & $20(90.9 \%)$ \\
\hline $\begin{array}{l}\text { ( } 25-30 \text { tahun) } \\
\text { Resiko tinggi } \\
\text { (<20 \& }>35 \text { thn) }\end{array}$ & $2(18.2 \%)$ & $0 \quad(0 \%)$ & $2(9.1 \%)$ \\
\hline \multicolumn{4}{|l|}{ Pendidikan } \\
\hline SD & $4(36.4 \%)$ & $2(18.2 \%)$ & $6 \quad(27.3 \%)$ \\
\hline SMP & $3(27.3 \%)$ & $6(54.5 \%)$ & $9(40.9 \%)$ \\
\hline SMA & $4(36.4 \%)$ & $3(27.3 \%)$ & $7(31.8 \%)$ \\
\hline \multicolumn{4}{|l|}{ Pekerjaan } \\
\hline Bekerja & $2(18.2 \%)$ & $7(63.6 \%)$ & $9 \quad(40.9 \%)$ \\
\hline Tidak Berkerja & $9(81.8 \%)$ & $4(36.4 \%)$ & $13(59.1 \%)$ \\
\hline \multicolumn{4}{|l|}{ Usia Kehamilan } \\
\hline$\leq 12$ minggu & $1(9.1 \%)$ & $2(18.2 \%)$ & $3(13.6 \%)$ \\
\hline $13-24$ minggu & $6(54.5 \%)$ & $7(63.6 \%)$ & $13(59.1 \%)$ \\
\hline$\geq 25$ minggu & $4(36.4 \%)$ & $2(18.2 \%)$ & $6 \quad(27.3 \%)$ \\
\hline
\end{tabular}

\section{Gambaran Asupan Zat Gizi}

Asupan zat gizi merupakan jumlah zat gizi yang masuk melalui konsumsi makanan dan minuman sehari-hari yang mengandung zat gizi makro dan mikro. Gambaran asupan zat gizi ibu hamil pada penelitian ini berdasarkan zat gizi makro yang meliputi asupan energi,asupan protein dan zat gizi mikro meliputi asupan zat besi dan asupan vitamin C. Asupan zat gizi diperoleh melalui metode recall 2 × 24 jam dan hasil recall diterjemahkan ke dalam nutrisurvey.

Tabel 2. Gambaran Asupan Zat Gizi berdasarkan Asupan Energi, Protein, Zat Besi dan Vitamin C Bulan April 2018 di Wilayah Kerja Puskesmas Lerep

\begin{tabular}{lcccc}
\hline \multirow{2}{*}{$\begin{array}{l}\text { Asupan } \\
\text { Zat Gizi }\end{array}$} & $\begin{array}{c}\text { Kelompok Perlakuan } \\
(\mathrm{n}=11)\end{array}$ & \multicolumn{2}{c}{$\begin{array}{c}\text { Kelompok Kontrol } \\
(\mathrm{n}=11)\end{array}$} \\
\cline { 2 - 5 } & Mean & Range & Mean & Range \\
\hline Energi & $2013 \pm$ & $1813-$ & $1836 \pm$ & $1332-$ \\
& 133 & 2253 & 289 & 2337 \\
Protein & $60.1 \pm 8$ & $44.8-$ & $57.9 \pm 16$ & $40.8-$ \\
& & 71.8 & & 90.6 \\
Zat & $71.2 \pm 2$ & $66.2-$ & $70.3 \pm 2$ & $66.2-$ \\
Besi & & 69.2 & & 74.5 \\
Vitamin & $72.8 \pm$ & $35.3-$ & $91 \pm 39$ & $46.3-$ \\
C & 53 & 200 & & 155.7 \\
& & & & \\
\hline
\end{tabular}


3. Kadar Hemoglobin Sebelum dan Setelah Intervensi

Kadar hemoglobin merupakan point utama pada penelitian ini, pengukuran kadar hemoglobin dilakukan dua kali yaitu sebelum intervensi (pre) dan sesudah intervensi (post) dengan metode autoanalyzer. Pengukuran dilakukan guna untuk melihat adanya perubahan yang terjadi pada kadar hemoglobin sebelum dan sesudah intervensi pada kelompok treatment (perlakuan) dan kelompok kontrol. Berikut adalah gambaran kadar hemoglobin ibu hamil anemia sebelum dan sesudah diberi perlakuan :

Tabel 3. Hasil Kadar Hemoglobin awal dan Sesudah Intervensi pada Ibu Hamil Anemia pada Bulan April - Mei 2018 di Wilayah Kerja Puskesmas Lerep

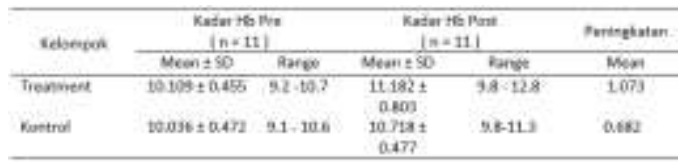

4. Pengaruh Pemberian Jus Jambu Biji terhadap Kadar Hemoglobin Ibu Hamil Anemia

Analisis pengaruh pemberian jus jambu biji terhadap kadar $\mathrm{Hb}$ ibu hamil anemia dilakukan dengan menggunakan uji ANOVA repeated measure. Sehingga diketahui besarnya kenaikan hadar hemoglobin setelah dilakukan perlakuan pemberian jus jambu biji.
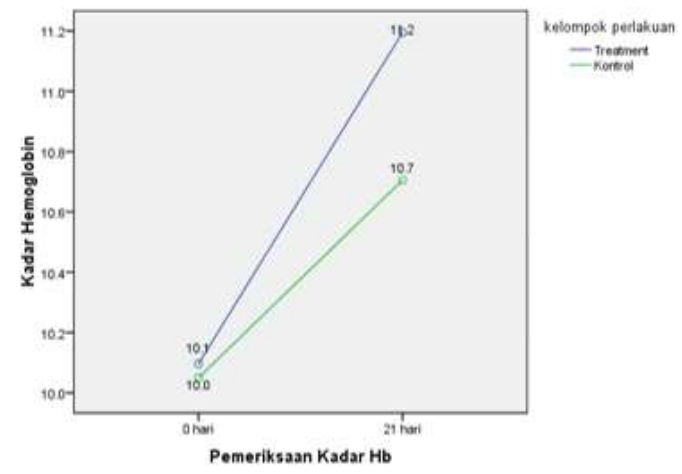

Gambar 1. Peningkatan Kadar Hemoglobin Sebelum dan Sesudah Intervensi pada Kedua Kelompok Ibu Hamil Anemia pada bulan April 2018

\section{PEMBAHASAN}

\section{Karakteristik Responden}

Karakteristik responden berdasarkan umur ibu menunjukkan bahwa mayoritas responden masuk dalam kategori kehamilan normal atau tidakberesikosebesar $81.8 \%$ pada kelompok treatment, $100 \%$ pada kelompok kontrol.Umur ibu merupakan salah satu faktor resiko yang berhubungan dengan kualitas kehamilan.Kehamilan normal (umur 20-35 tahun) merupakan usia reproduksi sehat, di usia tersebut jarang terjadi komplikasi kehamilan, organ reproduksi pada usia 20-35 tahun secara fisiologis telah dipersiapkan dengan baik dan matang untuk bereproduksi. Namun, beberapa kasus komplikasi kehamilan juga dapat terjadi pada ibu hamil di usia reproduksi sehat seperti kehamilan dengan terjadinya anemia. Hal tersebut dapat terjadi apabila sejak awal kehamilan tidak memenuhi kebutuhan masa hamil dengan cukup seperti pemenuhan kebutuhan zat besi dan vitamin C, maka ibu rentan mengalami anemia.

Karakteristik responden berdasarkan Pendidikan terakhir ibu menunjukkan bahwa mayoritas responden berpendidikan SMP sebanyak $27.3 \%$ pada kelompok treatment, $54.5 \%$ pada kelompok kontrol. Tingkat pendidikan mempunyai hubungan yang eksponensial dengan tingkat kesehatan apabila tingkat pengetahuan gizi ibu hamil baik maka diharapkan status gizi ibu dan janin juga baik. Berdasarkan hasil tersebut, ibu hamil yang berpendidikan SMA paling sedikit jika dibanding dengan ibu hamil yang pendidikan SMP dan SD. Sebagian besar ibu hamil lulusan SMP, maka proporsi ibu hamil yang berpendidikan rendah lebih banyak. Hal ini sesuai dengan penelitian yang dilakukan oleh Mariza (2016) dimana hasil penelitianyang di analisamenggunakan chisquare didapatkan $p$-value 0,026 sehingga $p$ value $<0,05$ yang berarti terdapat hubungan antara pendidikan dengan kejadian anemia.

Karakteristik responden bersadarkan kategori pekerjaan ibu menunjukkan bahwa mayoritas responden tidak bekerja sebanyak 81.8\% pada kelompok treatment, $36.4 \%$ pada kelompok kontrol.Pekerjaan seseorang dapat mempengaruhi pendapatan keluarga yang diperoleh. Hal ini sesuai dengan penelitian yang dilakukan Fifi, 2013 yang menunjukkan bahwa ada hubungan yang bermakna antara pendapatan dengan kejadian anemia pada ibu hamil $^{13}$. Penelitian ini juga sesuai dengan hasil penelitian yang dilakukan oleh Lulu (2009), 
menyatakan bahwa ibu hamil yang berpendidikan rendah memiliki kemungkinan yang lebih besar mengalami anemia yaitu sebesar 1,42 kali dibandingkan ibu hamil yang berpendidikan tinggi. ${ }^{14}$

Karakteristik responden berdasarkan umur kehamilan ibu menunjukkan bahwa mayoritas usia kehamilan (13 - 24 minggu) responden sebanyak $54.5 \%$ pada kelompok treatment dan $63.6 \%$ pada kelompok kontrol .Pada usiakehamilan 13-24 minggu (trimester II) hingga $\geq 25$ minggu (trimester III). Volume plasma meningkat sebesar $45 \%-65 \%$ dimulai pada trimester II kehamilan dan maksimum terjadi pada bulan ke 9, peningkatannya hingga $1.000 \mathrm{ml}$, terjadi penurunan menjelang aterm serta kembali normal 3 bulan setelah partus. Hal tersebut merupakan penyebab prevalensi anemia tinggi jika dibanding dengan trimester I. Hasil penelitian ini sesuai dengan hasil penelitian yang dilakukan oleh Dameria,2011 bahwa proporsi ibu hamil yang mengalami anemia terbanyak pada kelompok ibu hamil trimester III sebanyak $82,4 \%$ dan terbanyak kedua di trimester II sebanyak 71,4\%, sedangkan trimester I sebanyak $52 \%{ }^{15}$.

\section{Gambaran Asupan Zat Gizi}

Hasil analisis berdasarkan tabel 2, dapat dilihat gambaran asupan zat gizi yang dikonsumsi oleh responden meliputi asupan energi, protein, fe, vitamin C. Rerata asupan energi pada kelompok perlakuan dan kelompok kontrol masih tergolong dalam kategori kurang apabila dibandingkan dengan kebutuhan energi ibu hamil. Menurut Yogo Yuwono mengatakan ada hubungan yang bermakna antara tingkat kecukupan energi dengan kadar hemoglobin ibu hamil. Energi diperlukan untuk membantu proses gerakan otot saluran pencernaan, sehingga gerakan ini membantu saluran pencernaan tersebut dalam proses penyerapan zat besi pada usus.

Asupan protein pada kelompok perlakuan dan kelompok kontrol juga masih tergolong dalam kategori kurang jika dibandingkan dengan kebutuhan ibu hamil. Protein berperan penting dalam transportasi zat besi di dalam tubuh ${ }^{16}$.Asupan protein yang kurang akan mengakibatkan transportasi zat besi terhambat sehingga akan terjadi defisiensi zat besi yang ditandai dengan penurunan kadar hemoglobin dibawah nilai norma ${ }^{17}$. Hal ini sesuai dengan penelitian yang dilakukan oleh Anggi, 2014 bahwa terdapat hubungan antara asupan energi, protein dan besi terhadap kadar hemoglobin pada tenaga kerja wanita di PT Won Jin Indonesia ${ }^{18}$ dan sesuai dengan penelitian observasional pada 64 wanita usia subur di Biringkanaya Makasar yang menyatakan bahwa asupan protein memiliki hubungan yang signifikan dengan kadar hemoglobin ${ }^{19}$.

Selain asupan energi dan protein, asupan vitamin $\mathrm{C}$ sebelum intervensi juga masuk dalam kategori kurang. Hal ini sesuai dengan penelitian yang dilakukan oleh Heny, 2017 bahwa ada hubungan angka kecukupan vitamin $\mathrm{C}$ dengan kadar hemoglobin, sehingga apabila kecukupan vitamin $\mathrm{C}$ rendah atau kurang maka peluang terjadinya anemia pada ibu hamil semakin meningkat ${ }^{20}$. Vitamin C terlibat dalam mobilisasi simpanan besi terutama hemosiderin dalam limpa. Vitamin C diperlukan untuk meningkatkan penyerapan besi di dalam tubuh. Vitamin C mempunyai peranan yang sangat penting dalam penyerapan besi terutama dari besi nonhem yang banyak ditemukan dalam makanan nabati ${ }^{21}$.

\section{Kadar Hemoglobin Sebelum dan Sesudah} Intervensi

Rerata kadar hemoglobin $(\mathrm{Hb})$ pada kelompok treatment sebelum intervensi (pre) sebesar $10.109 \mathrm{gr} / \mathrm{dl}$ dan rerata $\mathrm{Hb}$ sesudah intervensi (post) sebesar 11.182, terjadi peningkatan pada kadar $\mathrm{Hb}$ sebelum dan sesudah intervensi yang ditunjukkan dengan nilai beda sebesar $1.073 \mathrm{gr} / \mathrm{dl}$.

Rerata kadar hemoglobin $(\mathrm{Hb})$ pada kelompok kontrol sebelum intervensi (pre) sebesar $10.036 \mathrm{gr} / \mathrm{dl}$ dan rerata $\mathrm{Hb}$ sesudah intervensi (post) sebesar 10.718, terjadi peningkatan pada kadar $\mathrm{Hb}$ sebelum dan sesudah intervensi yang ditunjukkan dengan nilai beda sebesar $0.682 \mathrm{gr} / \mathrm{dl}$.

\section{Pengaruh Jus Jambu Biji terhadap Kadar Hemoglobin}

Nilai probabilitas (sig) pada kelompok perlakuan (treatment) sebesar 0,439 karena $\mathrm{p}<$ 0,05 , maka terdapat pengaruh yang tidak signifikan. Hasil tersebut sudah dikontrol dengan asupan energi, asupan protein, asupan zat besi dan asupan vitamin C. Peningkatan kadar hemoglobin lebih tinggi pada kelompok treatment daripada kelompok kontrol, walau peningkatan tersebut tidak signifikan. Rerata peningkatan pada kelompok treatment antara sebelum dan sesudah intervensi sebesar 1,1 $\mathrm{gr} / \mathrm{dl}$ dan rerata peningkatan pada kelompok 
kontrol antara sebelum dan sesudah intervensi sebesar $0,7 \mathrm{gr} / \mathrm{dl}$.

Ibu hamil dianjurkan mengkonsumsi suplemen tablet Fe setiap hari demi memenuhi kebutuhan zat besi yang semakin meningkat pada ibu hamil, hal ini terjadi karena selama hamil volume darah meningkat $50 \%$, sehingga perlu lebih banyak zat besi untuk membentuk hemoglobin. Selain itu, pertumbuhan janin dan plasenta yang sangat pesat juga memerlukan banyak zat besi. Ibu hamil yang patuh mengkonsumsi tablet Fe dapat meningkatkan kadar nilai hemoglobin setidaknya 0,3 g/dl/minggu ${ }^{22}$.

Pada masa kehamilan terjadi perubahan hematologi dimana volume darah ibu mulai meningkat selama trimester pertama, meningkat lebih pesat pada trimester kedua dan kemudian meningkat dengan kecepatan jauh lebih lambat pada trimester ketiga hingga mendatar pada beberapa minggu terakhir kehamilan, perubahan hematolgi ini disebut hemodilusi ${ }^{23}$.

Secara fisiologis hemodilusi terjadi akibat bertambahnya sel-sel darah kurang jika dibandingkan dengan bertambahnya plasma sehingga terjadi pengenceran darah. Penambahan tersebut sebanding sebagai berikut : plasma 30\%, sel darah $18 \%$ dan hemoglobin $19 \%$. Hemodilusi secara fisiologi mempunyai fungsi sebagai berikut 1). Untuk memenuhi kebutuhan uterus yang membesar dengan sistem vascular yang mengalami hipertrofi berat, 2). Untuk melindungi ibu dan janin terhadap efek buruk gangguan aliran balik vena pada posisi terlentang dan tegak dan 3). Untuk melindungi ibu terhadap efek buruk pengeluaran darah pada saat persalinan ${ }^{23}$.

Penyerapan tablet $\mathrm{Fe}$ akan lebih maksimal apabila dikonsumsi bersamaan dengan konsumsi vitamin C. Vitamin C adalah salah satu zat gizi mikro yang berperan dalam pembentukan hemoglobin yang berpengaruh terhadap absorbsi dan pelepasan besi dari transferin ke dalam jaringan tubuh. Vitamin C mempunyai peranan yang sangat penting dalam penyerapan besi terutama dari besi nonhem yang banyak ditemukan dalam makanan nabati ${ }^{21}$. Dimana vitamin $\mathrm{C}$ akan mereduksi ion feri menjadi fero dalam usus halus sehingga mudah diabsorbsi. Proses reduksi tersebut akan semakin besar apabila $\mathrm{pH}$ dalam lambung semakin asam.Vitamin $\mathrm{C}$ dapat meningkatkan penyerapan besi non heme sebesar empat kali lipat dan dengan jumlah $200 \mathrm{mg}$ yang akan meningkatkan absorpsi zat besi sedikitnya $30 \%$.
Jambu biji merupakan buah yang banyak mengandung vitamin C. Jambu biji dapat mengatasi anemia karena didalam buah jambu biji merah mengandung zat gizi makro dan mikro, salah satu zat gizi mikro ialah vitamin C yang dapat memperlancar proses pembentukan hemoglobin sel darah merah. Dalam penelitian ini ibu hamil mengkonsumsi jus jambu biji dan tablet Fe secara rutin selama 20 hari.

Hasil penelitian ini membuktikan bahwa dengan mengkonsumsi tablet $\mathrm{Fe}$ bersamaan dengan konsumsi 150 gr jambu biji per hari secara rutin dapat meningkatkan kadar hemoglobin pada ibu hamil, karena seorang ibu hamil membutuhkan $85 \mathrm{mg}$ vitamin C per hari, sedangkan dalam 100 gram jambu biji mengandung $87 \mathrm{mg}$ vitamin C. Hasil penelitian ini sesuai dengan beberapa hasil penelitian terdahulu, pertama penelitian yang dilakukan oleh Yusnaini pada tahun 2014 yang menunjukkan bahwa ada pengaruh konsumsi jambu biji terhadap perubahan kadar hemoglobin pada ibu hamil anemia yang mendapat suplementasi tablet $\mathrm{Fe}^{24}$. Kedua, penelitian yang dilakukan oleh Argana, G, dkk pada tahun 2014 menunjukkan bahwa setiap bertambahnya frekuensi konsumsi makanan yang mengandung vitamin C 1 kali akan meningkatkan kadar hemoglobin sebesar 0.06 $\mathrm{gr} / \mathrm{dl}$, artinya semakin sering seseorang mengkonsumsi vitamin C maka semakin meningkat kadar nilai hemoglobin ${ }^{25}$. Ketiga, sesuai dengan penelitian yang dilakukan oleh Isnaeni pada tahun 2017 yang menunjukkan bahwa adanya pengaruh mengkonsumsi jambu biji terhadap peningkatan kadar Hemoglobin ibu hamil di Wilayah Kerja Puskesmas Lebaksiu Kabupaten Tegal ${ }^{11}$. Keempat, sesuai dengan penelitian yang dilakukan oleh Erinda pada tahun 2015 yang menunjukkan bahwa ada pengaruh konsumsi jambu biji dan tablet Fe terhadap perubahan kadar hemoglobin ${ }^{26}$. Kelima penelitian yang dilakukan oleh Joel Monarrez Espino, dkk pada tahun 2011 yang menunjukkan bahwa ada pengaruh pemberian jus jambu biji $300 \mathrm{ml}$ jus jambu biji yang mengandung $200 \mathrm{mg}$ asam askorbat selama 10 minggu terhadap peningkatan kadar hemoglobin pada anak usia 6-9 tahun ${ }^{27}$. Keenam, penelitian yang dilakukan oleh Vaidyanathan pada tahun 2016 yang menunjukkan bahwa ada pengaruh mengonsumsi jus jambu biji merah dengan madu terhadap peningkatan kadar hemoglobin, rata - rata peningkatan $0,02 \mathrm{gr} / \mathrm{dL}^{28}$ dan yang ketujuh, penelitian yang dilakukan oleh Krishnapillai Madhavan dkk menunjukkan 
bahwa penyerapan tablet besi non heme secara signifikan lebih besar pada kelompok yang mengkonsumsi tablet besi disertai jus jambu biji 29.

\section{KESIMPULAN}

Berdasarkan hasil penelitian yang telah dilakukan di Wilayah Kerja Puskesmas Lerep, Kecamatan Ungaran Barat Kabupaten Semarang pada bulan April tahun 2018 dapat disimpulkan bahwa pemberian jus jambu biji selama 20 hari dapat meningkatkan kadar hemoglobin sebesar 1.1 $\mathrm{gr} / \mathrm{dl}$ meskipun secara statistik tidak signifikan.

\section{SARAN}

1. Bagi Ibu Hamil

Ibu hamil disarankan untuk mengkonsumsi jus jambu biji dengan $150 \mathrm{gr}$ buah atau setara dengan dua buah jambu biji ukuran kecil baik sesudah atau sebelum mengkonsumsi tablet $\mathrm{Fe}$ agar zat besi yang dikonsumsi terserap secara maksimal oleh tubuh, karna jus jambu biji dapat menaikkan kadar hemoglobin yang berguna untuk mengurangi kejadian anemia.

2. Bagi Penelitian Selanjutnya

Dengan adanya beberapa keterbatasan dalam penelitian ini, kepada peneliti selanjutnya dapat mengadakan penelitian sejenis dengan jangka waktu penelitian lebih lama.

\section{DAFTAR PUSTAKA}

1. Ermalena. Indikator Kesehatan SDGs di Indonesia. Balai Kartini. 2017;

2. Asmaliah Hidayanti. Hubungan Pola Makan Dengan Kadar Hemoglobin Ibu Hamil Anemia Penerima Suplemen Zat Gizi Di Kabupaten Barru. Fakultas Kesehatan Masyarakat Universitas Hasanuddin : Makasar.2005;

3. Hartono, Bambang. Profil Kesehatan Indonesia 2005. Jakarta : Departemen Kesehatan Republik Indonesia. 2007;160.

4. Badan Penelitian dan Pengembangan Kesehatan. Riset Kesehatan Dasar (RISKESDAS) 2013. Lap Nas 2013. 2013;1-384

5. Rangkuti. Gambaran Faktor-Faktor Kejadian Anemia Pada Ibu Hamil Di Puskesmas Lerep Kecamatan Ungaran Barat Kabupaten Semarang. Semarang.2017;

6. Susanti, Kumala Mt. Farmakologi Kebidanan, Aplikasi Dalam Praktik Kebidanan. Trans Info
Media (Tim); 2011.

7. Dheny, Rohmatika. Supriyana. Perbandingan Pengaruh Pemberian Ekstrak Bayam Hijau Dengan Preparat Fe Terhadap Perubahan Kadar Hemoglobin Ibu Hamil Pasien Puskesmas. 2016;

8. Gunawan. Farmakologi Dan Terapi. Jakarta: Gaya Baru; 2007.

9. Goodman. Dasar Farmakologi Terapi. Jakarta: Ecg; 2008.

10. Evika Rachmaniar Hk. Pemanfaatan Sari Buah Jambu Biji Merah (Psidium Guajava Linn) Sebagai Antioksidan Dalam Bentuk Granul Effervescent. J Ji, Sci P. 2016;1.

11. Isnaeni A. Pengaruh Konsumsi Jus Jambu Biji Terhadap Peningkatan Kadar Hemoglobin Pada Ibu Hamil Anemia Di Puskesmas Lebaksiu Kabupaten Tegal. 2017;

12. Besuni A, Jafar N, Indriasari R, Studi P, Gizi I, Kesehatan F, Et Al. Nutrients Intake Relationship Forming Red Blood Cells With Hemoglobin Levels In Pregnant Women In Gowa. 0:1-10.

13. Fifi. M. Liow, Nova. H. Kapantow Nmb. Hubungan Antara Status Sosial Ekonomi Dengan Anemia Pada Ibu Hamil Di Desa Sapa Kecamatan Tenga Kabupaten Minahasa Selatan. Univ Sam Ratulangi Manad. 2013;

14. Lulu. Faktor Yag Berhubungan Dengan Status Anemia Pada Asuhan Antenatal Dipuskesmas Kecamatan Pasar Minggu Jakarta Selatan. Depok: Fkm Ui; 2009.

15. Dameria Magdalena Tambunan. Gambaran Kejadian Anemia Ibu Hamil Dan Faktor-Faktor Yang Berhubungan Di Wilayah Kerja Puskesmas Sei Apung Kabupaten Asahan Tahun 2011. In Depok: Universitas Indonesia; 2011.

16. Murray. Biokimia Harper. Jakarta: Ecg; 2003.

17. Almatsier S. Prinsip Dasar Ilmu Gizi. Jakarta: Pt Gramedia Pustaka Utama; 2009.

18. Mantika, A.I., Mulyati T. Hubungan Asupan Energi, Protein, Zat Besi Dan Aktivitas Fisik Dengan Kadar Hemoglobin Tenaga Kerja Wanita Di Pabrik Pengolahan Rambut Pt. Won Jin Indonesia. J Nutr Collage [Internet]. 2014;3(4):706-14. Available From: Https://Ejournal3.Undip.Ac.Id/Index.Php/Jnc/ Article/View/6890

19. Kurniati, Thaha Ar Jn. Hubungan Asupan Zat Gizi Dengan Kejadian Anemia Pada Wanita Prakonsepsi Di Kecamatan Bringkanaya Kota Makasar. Univ Hasanudin. 2013;

20. Heny Yuliati. Hubungan Tingkat Kecukupan Energi, Protein, Besi, Vitamin C Dan Suplemen Tablet Besi Dengan Kadar Hemoglobin Ibu Hamil Trimester li Dan lii. 2017;5:675-82. 
21. Zarianis. Efek Suplementasi Besi-Vitamin C Dan Vitamin C Terhadap Kadar Hemoglobin Anak Sekolah Dasar Yang Anemia Di Kecamatan Sayung Kabupaten Demak. 2006;

22. Manuaba. Kapita Selekta Penatalaksanaan Rutin Obsetri Ginekologi Dan Kb. Jakarta: Ecg; 2001.

23. Cunningham Fg, Gant Nf, Leveno,Kj Et Al. Williams Manual of Obstetrics. 21" Editio. New York: Mcgraw-Hill Medical Publising Div; 2003.

24. Yusnaini. Pengaruhkonsumsi Jambubiji (Psidium Guajava. L) Terhadap Perubahankadar Hemoglobin Pada Ibu Hamil Anemia Yang Mendapat Suplementasi Tablet Fe. 2014;

25. Argana G, Utari Kdm, Kerja Pk, Ri Dk, Gizi D, Masyarakat K. Vitamin C Sebagai Faktor Dominan Untuk Kadar Hemoglobin Pada Wanita Usia 20 - 35 Tahun. 2004;23(1).

26. Pratiwi En. Pengaruh Pemberian Jus Jambu Biji Terhadap Perubahan Kadar Hemoglobin Dan Kadar Feritin Ibu Hamil Yang Mendapat Tablet Fe. 2015;

27. Monárrez-Espino J, Greiner T. Randomized Trial Of Guava As A Source Of Ascorbic Acid To Reduce Iron Deficiency In Indigenous Schoolchildren Of Mexico Randomized Placebo-Controlled Trial Of Guava Juice As A Source of Ascorbic Acid To Reduce Iron Deficiency In Tarahumara Indigenous Schoolchildren Of Northern. 2007;(January).

28. R.Reeta M.Sc (N) And Dr.Rajeswari Vaidyanathan, M.Sc P. A Study To Compare The Effectiveness Of Gooseberry Juice With Honey Versus Ripe Guava Juice With Honey On The Level Of Haemoglobin Among Adolescent Girls With Anaemia Studying In Selected Schools At Dh. Int J Pharma Bio Sci Issn. 2016;7(3):959-62.

29. Krihnapillai Madhavan Nair, Ginella N.V. Brahman, Madhari S. Radhika, Roy Choudry Dripta, Punjal Ravinder, Nagalla Balakrishna, Zhengsheng Chen Kmh And Saa. Inclusion Of Guava Enhances Non-Heme Iron Biovability But Not Fractional Zinc Absorption From A Rice-Based Meal In Adolescents. J Nutr. 2013; 